\title{
Review
}

\section{COVID-19 Vaccines: An Overview of Different Platforms}

\author{
Dmitry Kudlay ${ }^{1, *(1)}$ and Andrey Svistunov ${ }^{2}$
}

1 Department of Pharmacology, Institute of Pharmacy, I.M. Sechenov First Moscow State Medical University (Sechenov University), St. Trubetskaya, 8, Building 2, 119991 Moscow, Russia

2 I.M. Sechenov First Moscow State Medical University (Sechenov University), St. Trubetskaya, 8, Building 2, 119991 Moscow, Russia; svistunov_a_a@staff.sechenov.ru

* Correspondence: d624254@gmail.com; Tel.: +7-(499)-248-05-53

Citation: Kudlay, D.; Svistunov, A. COVID-19 Vaccines: An Overview of Different Platforms. Bioengineering 2022, 9, 72. https://doi.org/ 10.3390/bioengineering 9020072 Academic Editor: Francesco Cappello

Received: 29 December 2021 Accepted: 7 February 2022

Published: 12 February 2022

Publisher's Note: MDPI stays neutral with regard to jurisdictional claims in published maps and institutional affiliations.

Copyright: (c) 2022 by the authors Licensee MDPI, Basel, Switzerland. This article is an open access article distributed under the terms and conditions of the Creative Commons Attribution (CC BY) license (https:// creativecommons.org/licenses/by/ $4.0 /)$.

\begin{abstract}
Vaccination is one of the key strategies to stop the COVID-19 pandemic. This review aims to evaluate the current state of vaccine development and to determine the issues that merit additional research. We conducted a literature review of the development of COVID-19 vaccines, their effectiveness, and their use in special patient groups. To date, 140 vaccines are in clinical development. Vector, RNA, subunit, and inactivated vaccines, as well as DNA vaccines, have been approved for human use. Vector vaccines have been well studied prior to the COVID-19 pandemic; however, their long-term efficacy and approaches to scaling up their production remain questionable. The main challenge for RNA vaccines is to improve their stability during production, storage, and transportation. For inactivated vaccines, the key issue is to improve their immunogenicity and effectiveness. To date, it has been shown that the immunogenicity of COVID-19 vaccines directly correlates with their clinical efficacy. In view of the constant mutation, the emerging new SARS-CoV-2 variants have been shown to be able to partially escape post-vaccination immune response; however, most vaccines remain sufficiently effective regardless of the variant of the virus. One of the promising strategies to improve the effectiveness of vaccination, which is being studied, is the use of different platforms within a single vaccination course. Despite significant progress in the development and study of COVID-19 vaccines, there are many issues that require further research.
\end{abstract}

Keywords: vaccine; prevention; vector; mRNA; peptides; COVID-19; boost

\section{Introduction}

According to the World Health Organization (WHO), globally, as of 19 November 2021, there have been 255,324,963 confirmed cases of coronavirus disease 2019 (COVID-19), including 5,127,696 deaths [1]. Experts have observed a decline in economic growth of $3.4-7.6 \%$ in 2020; the rate is expected to return to pre-pandemic levels by 2024 at the earliest [2].

Epidemic control strategies, including public transport closures, switching to remote work, and full lockdowns turned out to be effective measures to combat the spread of the disease [3-5]. However, such measures greatly affect the global economy, therefore, they cannot be implemented for a long time.

During the pandemic, various COVID-19 treatment strategies have been developed and widely introduced to clinical practice. Antimalarials and some antivirals, such as lopinavir and ritonavir, which had been used at the early stages of the pandemic, were later found to be ineffective and/or associated with risks to patient health [6]. To date, an effective curative therapy that can be used in a wider population is still lacking. Therefore, only symptomatic and pathogenesis-based treatments are available, even for patients with moderate to severe disease [6-9]. In such a situation, the most promising strategy for overcoming the pandemic is vaccination of the entire population.

Data from the COVID-19 Vaccine Market Dashboard [10] shows that the average cost per COVID-19 vaccine dose ranges between USD 2 and 40 (Vaxzevria, AstraZeneca-USD 
4.6, Ad26.COV2.S, Janssen-USD 9.6, Sputnik V, Gamaleya Research Institute-USD 17.38, BNT162b2, Pfizer/Biontech-USD 13.4, Spikevax, Moderna-USD 29.63, BBIBP-CorV, Sinopharm-USD 19.79, NVX-CoV2373, Novavax-USD 20.9). This represents a significant financial burden for low-income countries. A slower and delayed vaccination rollout in low- and middle-income countries has left them vulnerable to COVID-19 variants, new surges of the virus, and a slower recovery out of the crisis. High-income countries started vaccination, on average, two months earlier than low-income countries, and vaccination coverage in low-income countries is still strikingly low [11]. About $60.8 \%$ of the global population received at least one dose of a vaccine, while the vaccination rate in low-income countries was only $9.8 \%$ [12]. In European countries, $74.3 \%$ of the adult population have been fully vaccinated; in the meantime, in Russia, this rate has only been $47.6 \%$ [1]. Thus, as of the middle of January 2022, about 1800 versus over 4700 deaths per week have been reported in the UK and in Russia, respectively [1]. Over time, it becomes more important to consider vaccination of children and adolescents, as well as the most effective ways to use vaccines and to maintain their effectiveness to keep up with new mutations of the virus. At the same time, safety and efficacy of vaccines for COVID-19 prevention, as well as the strategies for using them in the general population and in special populations, are being extensively discussed. To identify research priorities, this review discusses the existing vaccine platforms and the main available data on the clinical use of vaccines.

\section{Vaccine Platforms}

To date, 334 COVID-19 vaccines have been approved or are being developed worldwide; of these, 194 are in preclinical development and 140 are being investigated in clinical trials. This review discusses only the vaccines in clinical development. Figure 1. shows the platforms for vaccine development [13].

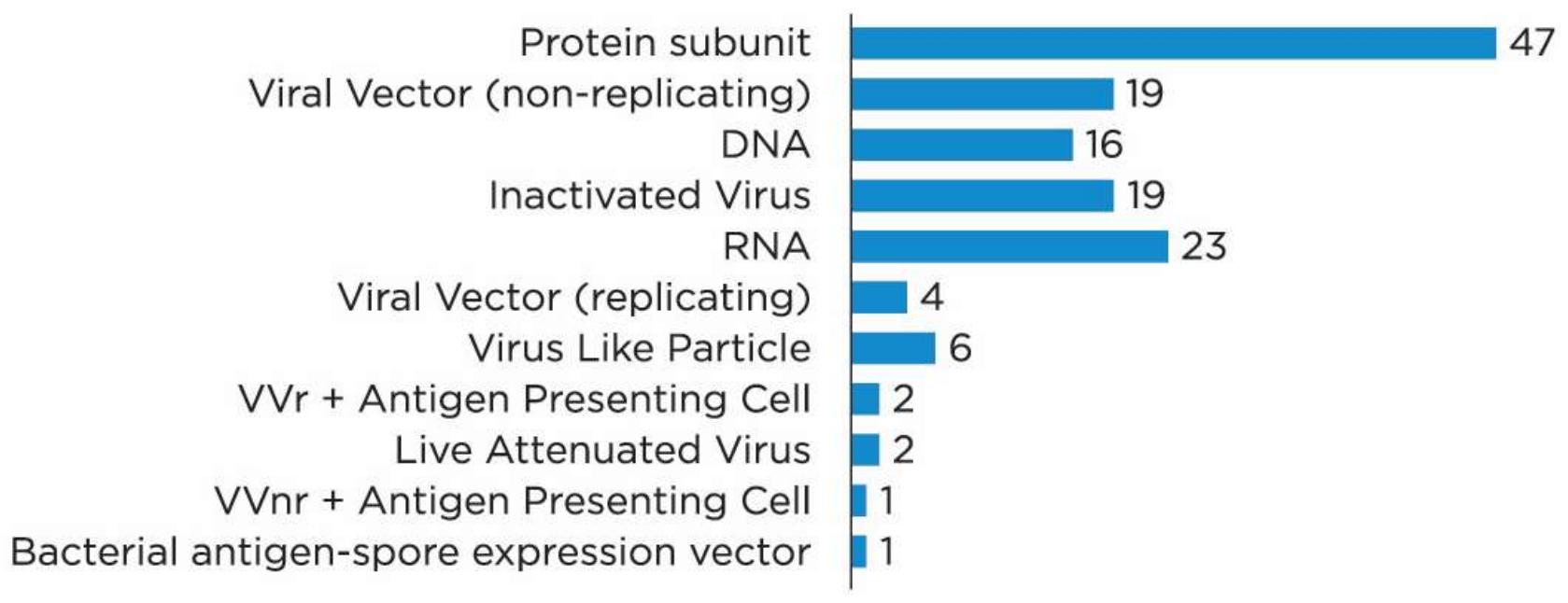

Figure 1. Platforms for vaccine products in clinical development [13]. Notes: DNA, deoxyribonucleic acid; RNA, ribonucleic acid; VVr, replicating viral vector; VVnr, non-replicating viral vector.

The majority of the vaccines are protein subunit (PS) vaccines, also called peptide vaccines. The ribonucleic acid (RNA) vaccines, as well as inactivated virus (IV), nonreplicating viral vector (VVnr), and deoxyribonucleic acid (DNA) vaccines are also common (Figure 2). There are also single vaccines containing a viral vector that can replicate (replicating viral vector, VVr) virus-like particles (VLP) VVr with antigen-presenting cells (APC), live attenuated virus, VVnr with APC, or bacterial antigen-spore expression vector, in clinical development. In the meantime, 33 vaccines have been approved in at least one country (Table 1) [14]. 


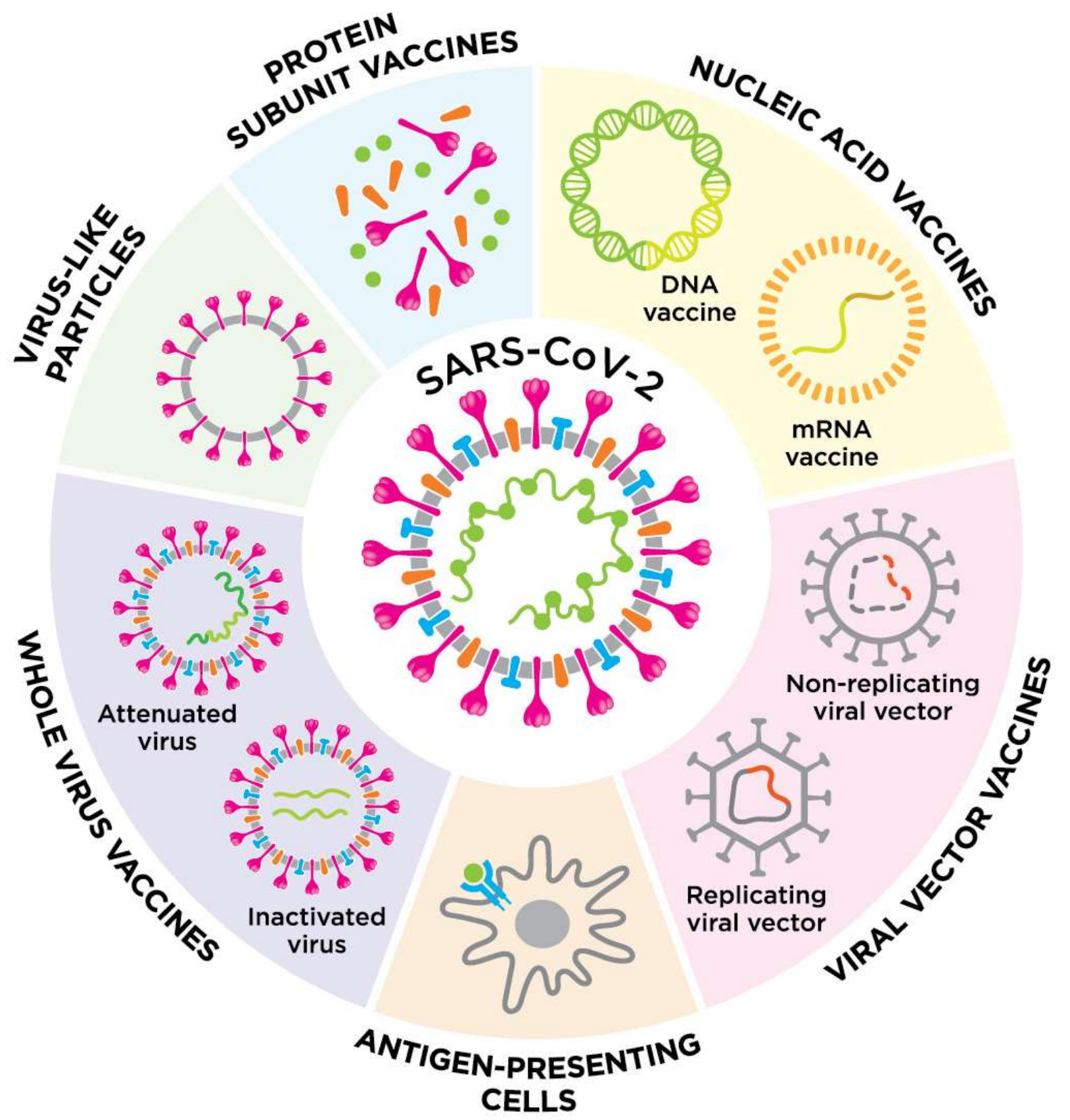

Figure 2. An overview of the different vaccine platforms against COVID-19.

Table 1. COVID-19 vaccines approved by $\geq 1$ countries [14].

\begin{tabular}{cccc}
\hline \multirow{2}{*}{ Platform } & Vaccine Name & Manufacturer & $\begin{array}{c}\text { No. of Countries, Where a } \\
\text { Vaccine Was Approved }\end{array}$ \\
\hline \multirow{2}{*}{ VVnr } & Ad26.COV2.S & Janssen, Beerse, Belgium & 106 \\
\cline { 2 - 4 } & Sputnik V & Gamaleya National Center of Epidemiology and & 74 \\
\cline { 2 - 4 } & Sputnik Light & Microbiology, Moscow, Russian Federation & 24 \\
\cline { 2 - 4 } & AZD1222, Vaxzevria & Oxford University / AstraZeneca, Södertälje, Sweden & 137 \\
\cline { 2 - 4 } & Ad5-nCoV, Convidecia & Serum Institute of India, Pune, India (based on & 47 \\
\hline
\end{tabular}


Table 1. Cont.

\begin{tabular}{|c|c|c|c|}
\hline Platform & Vaccine Name & Manufacturer & $\begin{array}{l}\text { No. of Countries, Where a } \\
\text { Vaccine Was Approved }\end{array}$ \\
\hline \multirow{3}{*}{ RNA } & BNT162b2, Comirnaty & Pfizer/Biontech, Mainz, Germany & 137 \\
\hline & mRNA-1273, Spikevax & Moderna, Cambridge, MA, USA & 85 \\
\hline & TAK-919 & $\begin{array}{l}\text { Takeda, Tokyo, Japan (based on } \\
\text { Moderna technology) }\end{array}$ & 1 \\
\hline \multirow{13}{*}{ PS } & CIGB-66, Abdala & $\begin{array}{l}\text { Cuban Center for Genetic Engineering and } \\
\text { Biotechnology, Havana, Republic of Cuba }\end{array}$ & 6 \\
\hline & EpiVacCorona & $\begin{array}{l}\text { "Vector", National Research Center for Virology and } \\
\text { Biotechnology, Novosibirsk, Russian Federation }\end{array}$ & 4 \\
\hline & MVC-COV1901 & Medigen, Taipei, Taiwan & 2 \\
\hline & ZF2001 & $\begin{array}{c}\text { Anhui Zhifei Longcom, Beijing, People's Republic } \\
\text { of China }\end{array}$ & 3 \\
\hline & Corbevax & Biological E Limited, Hyderabad, India & 1 \\
\hline & $\begin{array}{c}\text { Aurora-CoV } \\
(\text { EpiVacCorona-N) }\end{array}$ & $\begin{array}{l}\text { "Vector", National Research Center for Virology and } \\
\text { Biotechnology, Novosibirsk, Russian Federation }\end{array}$ & 1 \\
\hline & Soberana 02 & \multirow{2}{*}{$\begin{array}{l}\text { Instituto Finlay de Vacunas Cuba, Havana, Republic } \\
\text { of Cuba }\end{array}$} & 4 \\
\hline & Soberana Plus & & 1 \\
\hline & $\begin{array}{l}\text { Recombinant SARS-CoV-2 } \\
\text { Vaccine (CHO Cell, } \\
\text { NVSI-06-08) }\end{array}$ & $\begin{array}{l}\text { National Vaccine and Serum Institute, Beijing, } \\
\text { People's Republic of China }\end{array}$ & 1 \\
\hline & Nuvaxovid (NVX-CoV2373) & Novavax, Gaithersburg, USA & 32 \\
\hline & Razi Cov Pars & $\begin{array}{l}\text { Razi Vaccine and Serum Research Institute, } \\
\text { Karaj, Iran }\end{array}$ & 1 \\
\hline & $\begin{array}{l}\text { COVOVAX (Novavax } \\
\text { formulation) }\end{array}$ & Serum Institute of India, Pune, India & 3 \\
\hline & SpikoGen, COVAX-19 & Vaxine/CinnaGen Co., Tehran, Iran & 1 \\
\hline \multirow{10}{*}{ IV } & Covaxin & Bharat Biotech, Hyderabad, India & 13 \\
\hline & KoviVac & $\begin{array}{l}\text { Chumakov Federal Scientific Center for Research } \\
\text { and Development of Immune-and-Biological } \\
\text { Products of Russian Academy of Sciences, Moscow, } \\
\text { Russian Federation }\end{array}$ & 3 \\
\hline & QazVac & $\begin{array}{c}\text { Research Institute for Biological Safety Problems, } \\
\text { Guardeyskiy, Republic of Kazakhstan }\end{array}$ & 2 \\
\hline & $\begin{array}{l}\text { KCONVAC (Vero Cells), } \\
\text { KconecaVac }\end{array}$ & $\begin{array}{c}\text { Minhai Biotechnology Co., Beijing, People's } \\
\text { Republic of China }\end{array}$ & 2 \\
\hline & $\begin{array}{l}\text { COVIran Barekat, COVID-19 } \\
\text { Inactivated Vaccine }\end{array}$ & Shifa Pharmed Industrial Co, Karaj, Iran & 1 \\
\hline & $\begin{array}{l}\text { Covilo, BBIBP-CorV } \\
\text { (Vero Cells) }\end{array}$ & Sinopharm (Beijing), People's Republic of China & 88 \\
\hline & Inactivated (Vero Cells) & Sinopharm (Wuhan), People's Republic of China & 2 \\
\hline & CoronaVac & Sinovac, Beijing, People's Republic of China & 53 \\
\hline & Turkovac & Health Institutes of Turkey, Istanbul, Turkey & 1 \\
\hline & FAKHRAVAC (MIVAC) & $\begin{array}{l}\text { Organization of Defensive Innovation and Research, } \\
\text { Tehran, Iran }\end{array}$ & 1 \\
\hline DNA & ZyCoV-D & Zydus Cadila, Ahmedabad, India & 1 \\
\hline
\end{tabular}




\section{Vaccines Containing Non-Replicating Viral Vector}

VVnr vaccines contain SARS-CoV-2 genetic material encapsulated in a viral (vector) envelope; the vector has the ability to enter human cells, but it cannot replicate there. Viral vectors have been produced and used in medicine for a long time. Initially, vectors were more popular in gene therapy; however, they have been used to develop vaccines for more than 25 years [15]. The most common vectors include adenoviruses, herpes viruses, alphaviruses, as well as measles, variola, and vesicular stomatitis viruses. Classical vectors (measles and variola viruses) have some obvious advantages, including persistent or even lifelong immunity; however, their use is currently limited by the difficulties in controlling the production of these vectors and the relatively high risk of virus mutations during the manufacturing [16].

At the time of this review, all registered VVnr vaccines are based on one or more of the following adenoviral vectors:

- Vaxzevria/Covishield vaccine is composed of ChAdOx1 chimpanzee adenovirus vector (previously known as ChAdY25) [17,18].

- Ad26.COV2.S vaccine contains recombinant human adenovirus type 26 (Ad26) vector $[19,20]$.

- Sputnik V and Sputnik Light vaccines are based on recombinant adenovirus type 26 and type 5 (Ad26 and Ad5) vectors [21-23].

- $\quad$ Ad5-nCoV vaccine contains Ad5 adenovirus vector [24].

All vaccines listed above are two dose (two vaccine doses are required for complete vaccination), except for the Janssen and Sputnik Light vaccines, which are administered once. All vaccine vectors carry a viral RNA fragment that encodes a viral spike (S) protein, which mediates the binding and translocation of the virus into the cell. Thus, the synthesis of the SARS-CoV-2 antigen occurs in human cells after the administration of a vaccine [25].

Vector vaccines have a number of clinical advantages. VVnr vaccines elicit a relatively persistent and potent immune response [16], thus providing long-term protection against infection and severe disease. Even a single VVnr vaccine injection is associated with sufficient immunogenicity to achieve protective antibody titers [26]. This allows for a development and approval of Sputnik Light and Ad26.COV2.S single-phase vaccines. A hypothesized decrease in the immune response in the presence of natural immunity to the vector or vector-like viruses has not been confirmed in the studies [27]. In the meantime, the problem of preserving VVnr immunogenicity upon repeated administration of vaccines remains relevant [28]. The first way to solve the problem is the alternation or use of different vectors, which has been implemented in the Sputnik V vaccine [21]. The second way to avoid vector neutralization is to use well-known technologies, including pegylated forms [29], which are currently in preclinical development and are mainly used in gene therapy [30,31], or dosage forms with microspheres [32]. Another significant drawback faced by many companies is the difficulty in scaling up the production of vector vaccines due to the peculiarities of vector production that require replication in cells cultured on solid substrates. Moreover, the direct process of assembling the vector with SARS-CoV-2 genetic material limits the scalability of production.

Despite the existing difficulties in production and not fully resolved problems of longterm efficacy and its maintenance upon repeated administrations of the same vaccine, VVnr is one of the most promising platforms for the development of new COVID-19 vaccines and the modification of existing ones.

\section{Vaccines Containing Viral Ribonucleic Acid}

The COVID-19 pandemic has fast tracked the development of new ribonucleic acid (RNA) vaccine technology. Vaccines based on nucleic acids act due to the delivery of genetic material encoding immunogenic fragments of the virus into human cells. After the delivery of genetic material (RNA or deoxyribonucleic acid (DNA), viral proteins are synthesized, initiating the immune response and the synthesis of antibodies to the virus [33]. There are three main technologies for the development of nucleic acid vaccines: 
- Vaccines that contain DNA (DNA vaccines). When reaching the host cells, DNA is transcribed into messenger RNA, followed by protein synthesis [33].

- Vaccines that contain messenger RNA (mRNA). The use of mRNA helps bypass transcription and simplify the synthesis of antigens [33].

- Vaccines based on mRNA, capable of self-amplification due to the additional inclusion of nsP1-4 sequence of alphavirus protein in the original RNA, which amplifies the coding region of the antigen mRNA; another option is the use of trans-amplifying mRNA, where nsP1-4 mRNA is a separate fragment [34].

DNA vaccines are considered a less promising platform due to the presence of additional stages in the immune response formation, which may be excluded with RNA vaccines. However, the first DNA vaccine for COVID-19 (ZyCoV-D) has been approved in India [35].

Self-amplifying RNA elicits a more potent immune response and requires lower doses [36]; however, simpler methods of immunization have apparently been preferred due to the necessity of a rapid development of COVID-19 vaccines. Pfizer and Moderna vaccines contain an mRNA fragment that encodes an entire $S$ protein containing the largest number of immunogenic epitopes of the virus [37,38]. The development and production of RNA vaccines are associated with two significant technological barriers. RNA vaccines require the use of delivery systems that can protect genetic material from the host organism until it is delivered to target cells. In the two approved RNA vaccines (BNT162b2 and mRNA-1273), the problem has been solved by lipid nanoparticles for RNA delivery $[37,38]$. Another problem is easy RNA degradation in the external environment [33]. To stabilize mRNA and prevent its degradation, modified nucleosides have been incorporated into the existing vaccines $[37,38]$. However, the use of modified nucleosides does not completely solve the problem of mRNA instability and easy degradation. Therefore, mRNA vaccines require supply chains with strict requirements for ultra-low temperatures for transportation and storage [39].

Overall, mRNA is a promising and practically effective technological platform. At the same time, the main challenge for mRNA vaccines remains the stability of mRNA during production, transportation, and administration to patients. To increase the availability of mRNA vaccines, this problem has to be overcome.

\section{Vaccines Containing Viral Proteins}

Virus proteins with immunogenic potential as an active component of vaccines are a well-developed technological platform; using this platform, a number of vaccines have been developed for the prevention of infectious diseases, including hepatitis B and C, influenza, pertussis, and human papillomavirus [40]. According to WHO, 47 and 75 vaccines containing SARS-CoV-2 proteins are in clinical and preclinical development, respectively [13].

To develop COVID-19 vaccines, the entire S protein (Nuvaxovid (NVX-CoV2373), MVC-COV1901) or its receptor-binding domain (RBD) (Abdala (CIGB-66)), which is responsible for the binding of the virus to the angiotensin-converting enzyme (ACE) 2 receptor, are mainly used [41]. The WHO considers the EpiVacCorona vaccine to be a protein vaccine, but it contains peptide fragments of the SARS-CoV-2 S protein [42]. The results of studies on the effectiveness of the EpiVacCorona vaccine have not yet been published; only data from an independent study are available [43].

The advantages of protein vaccines include the streamlined production and more acceptable stability in the external environment [40]. On the other hand, in most cases, protein vaccines require an adjuvant to boost the immune response [44]. In addition, some experts suggest a possible Th-1/Th-2 response polarization with subunit vaccines [45]; however, the $\mathrm{S}$ protein induces a balanced immune response from CD4+ and CD8+ T-lymphocytes with maintained synthesis of antibodies, including virus-neutralizing ones [46].

The development of protein vaccines is associated with a long search for a sufficiently immunogenic target to be introduced into a vaccine. Despite a large number of candidate vaccines developed using this platform, only several vaccines have been registered to date, 
mainly in the countries of origin; the rest of the vaccines are to be registered in case of successful completion of phase $2 / 3$ clinical trials.

Overall, protein vaccines are a well-studied platform that has the necessary prerequisites for production and use. At the same time, the manufacturers face obstacles in vaccine approval that need to be overcome.

\section{Vaccines Containing Inactivated Virus}

Inactivated vaccines, as well as live attenuated vaccines, are the platforms with the longest history. To date, according to the $\mathrm{WHO}, 10$ inactivated vaccines have been registered for COVID-19 prophylaxis, with two vaccines (BBIBP-CorV and CoronaVac) being registered in 88 and 53 countries, respectively, making them one of the most widely used vaccines.

Due to the relative simplicity of the inactivated vaccine production and the possibility of rapid deployment of mass production and appropriate adjustment of the technological process (for example, changes in a virus strain), this technology is still widely used [47,48]. At the same time, the production of inactivated vaccines requires thorough batch control, since an impairment of inactivation can lead to a massive wave of infection [48]. Another significant disadvantage of inactivated vaccines may be the relatively low immunogenicity compared to that of mRNA or vector vaccines. One study showed that neutralizing antibody titers after vaccination with the Pfizer vaccine were significantly higher than in patients who received the CoronaVac vaccine [49]. On the one hand, a decrease in immunogenicity may lead to lower clinical efficacy, but on the other hand, these vaccines are more appropriate for medically compromised patients, since the risk of adverse reaction is a more significant factor for choosing a vaccine for such patients compared to the general population.

Inactivated vaccines are a well-established platform; however, the manufacturing process requires thorough control of virus inactivation, and further modifications of approved or developed vaccines may be required to improve their immunogenicity and efficacy.

\section{Other Promising Platforms}

Among other technological platforms used for vaccines in clinical development, antigen-presenting cell (APC) vaccines are of particular interest. APC-based vaccines contain laboratory dendritic cells, which carry the viral antigen on their surface. Thus, after the administration of the vaccine to the patient, the process of antigen presentation to the host's immune cells and the formation of post-vaccination immunity are significantly accelerated [50]. To date, the technology is mainly being developed in oncology for the treatment of solid tumors. APC vaccines for COVID-19 prophylaxis are being studied in clinical trials [51].

\section{Delivery of Different Types of Vaccines}

According to the guidelines of the World Health Organization (WHO) [13], most COVID-19 vaccines are designed to be delivered by the injectable route. However, the oral route of administration (Vaxart's Oral Mucosal COVID-19 vaccine, IosBio's OraPro-COVID$19^{\mathrm{TM}}$ vaccine) has been described. The oral tablet versions of the COVID-19 vaccine would be used to reach regions where proper healthcare staff or professionals are not available, especially in the underdeveloped countries. The tablet form of the vaccine would aid a common person with no access to a proper vaccination site, as it would eliminate the need for any healthcare professional, as well as the fear of common side effects of the injectables, such as malaise, pain, and inflammation [52].

\section{Immunogenicity and Safety of Vaccines}

The immunogenicity of a vaccine is a key parameter reflecting its effectiveness. According to the WHO and the European Medicines Agency (EMA) guidelines, immunogenicity must be assessed in clinical development programs of all vaccines before initiating ef- 
fectiveness studies. The guidelines recommend the assessment of not only the effective immunogenicity (titers of neutralizing antibodies), but also the effect of vaccines on T-cell immunity to evaluate potential long-term efficacy $[53,54]$.

The Pfizer and Sinovac vaccines may be an example of the relationship between the immunogenicity of COVID-19 vaccines and their effectiveness. The administration of the mRNA vaccine led to the formation of significantly higher titers of virus neutralizing antibodies [49], which were associated with effectiveness in preventing COVID-19; the effectiveness of Pfizer and Sinovac vaccines is 95 and $83.5 \%$, respectively [55,61]. An in silico study evaluated the effect of neutralizing antibodies synthesized following the administration of various vaccines on their clinical effectiveness. The most immunogenic vaccines were Pfizer, Moderna, and Novavax, which were associated with antibody titers 2-4 times higher than those obtained in convalescents, as well as the Sputnik vaccine, which led to antibody titers 1-1.5 times higher than those in convalescents. Following the administration of AstraZeneca or Janssen vaccines, the antibody titers were two times lower than those in the convalescents. As for the CoronaVac vaccine, the amount of antibodies was about six times lower than that following the infection. Mathematical modeling showed that the titers of neutralizing antibodies after vaccination linearly correlated with the effectiveness of the vaccines [62].

Immunogenicity can influence directly the safety and tolerability profile of vaccines. In clinical trials, the incidence of adverse events was significantly higher following the administration of mRNA and vector vaccines (local reactions in $40-89 \%$ of cases and systemic reactions in $44-86 \%$ of cases) than after the injection of inactivated vaccines (injection site reactions in 5-23\% of cases, systemic reactions in $4-18 \%$ of cases) [63].

The immunogenicity of vaccines characterizes their clinical effectiveness (Table 2). At the same time, immunogenicity determines the safety and tolerability of vaccines, which is essential when choosing a vaccine for vulnerable populations.

Table 2. Efficacy and safety of the most important COVID-19 vaccines.

\begin{tabular}{|c|c|c|c|c|c|}
\hline Vaccine & Type & Dose Regimen & $\begin{array}{c}\text { Prevention of } \\
\text { Symptomatic } \\
\text { Infection, \% (95\% CI) }\end{array}$ & $\begin{array}{l}\text { Prevention of } \\
\text { Severe Infection, } \\
\quad \%(95 \% \mathrm{CI})\end{array}$ & Main Adverse Events \\
\hline $\begin{array}{c}\text { BNT162b2 } \\
{[55,56]}\end{array}$ & mRNA & $\begin{array}{c}2 \text { doses, 3-week } \\
\text { interval }\end{array}$ & $95.0(90.3-97.6)$ & $88.9(20.1-99.7)$ & $\begin{array}{c}\text { Pain, erythema, and swelling at } \\
\text { the injection site } \\
\text { Weakness, myalgia, chills }\end{array}$ \\
\hline $\begin{array}{c}\text { mRNA-1273 } \\
\text { [57] }\end{array}$ & mRNA & $\begin{array}{c}2 \text { doses, 4-week } \\
\text { interval }\end{array}$ & $93.2(91.0-94.8)$ & $98.2(92.8-99.6)$ & $\begin{array}{l}\text { Pain, erythema, and swelling at } \\
\text { the injection site } \\
\text { Axillary lymph node swelling } \\
\text { and tenderness } \\
\text { Fever, headache, weakness, } \\
\text { myalgia, chills, nausea/vomiting }\end{array}$ \\
\hline $\begin{array}{c}\text { Ad26.COV2.S } \\
{[58]}\end{array}$ & VV & Single dose & $66.5(55.5-75.1)$ & $85.4(54.2-96.9)$ & $\begin{array}{c}\text { Pain, erythema, and swelling at } \\
\text { the injection site } \\
\text { Weakness, myalgia, chills }\end{array}$ \\
\hline $\begin{array}{c}\text { ChAdOx1 } \\
\text { nCoV-19 [59] }\end{array}$ & VV & $\begin{array}{c}2 \text { doses, } 4 \text {-week } \\
\text { interval }\end{array}$ & $67.1(52.3-77.3)$ & - & $\begin{array}{c}\text { Pain, erythema, and swelling at } \\
\text { the injection site } \\
\text { Weakness, myalgia, chills }\end{array}$ \\
\hline $\begin{array}{l}\text { Sputnik V } \\
\text { [21] }\end{array}$ & VV & $\begin{array}{c}2 \text { doses, 3-week } \\
\text { interval }\end{array}$ & $91.1(83.8-95.1)$ & $100(94.4-100)$ & $\begin{array}{c}\text { Pain, erythema, and swelling at } \\
\text { the injection site } \\
\text { Weakness, myalgia, chills }\end{array}$ \\
\hline $\begin{array}{l}\text { BBIBP-CorV } \\
\text { [60] }\end{array}$ & IV & $\begin{array}{c}2 \text { doses, 4-week } \\
\text { interval }\end{array}$ & $78.1(64.9-86.3)$ & - & $\begin{array}{c}\text { Pain, erythema, and swelling at } \\
\text { the injection site } \\
\text { Fever, headache, cough }\end{array}$ \\
\hline
\end{tabular}


Table 2. Cont.

\begin{tabular}{|c|c|c|c|c|c|}
\hline Vaccine & Type & Dose Regimen & $\begin{array}{c}\text { Prevention of } \\
\text { Symptomatic } \\
\text { Infection, \% (95\% CI) }\end{array}$ & $\begin{array}{l}\text { Prevention of } \\
\text { Severe Infection, } \\
\quad \%(95 \% \mathrm{CI})\end{array}$ & Main Adverse Events \\
\hline $\begin{array}{c}\text { CoronaVac } \\
{[61]}\end{array}$ & IV & $\begin{array}{c}2 \text { doses, 4-week } \\
\text { interval }\end{array}$ & $83.5(65.4-92.1)$ & - & $\begin{array}{l}\text { Pain, erythema, and swelling at } \\
\text { the injection site } \\
\text { Weakness, myalgia, nausea, chills }\end{array}$ \\
\hline
\end{tabular}

Notes: VNA, virus neutralizing antibodies; $\mathrm{CI}$, confidence interval; IV, inactivated virus; mRNA, messenger ribonucleic acid; $\mathrm{VV}$, viral vector.

\section{Vaccine Selection Approaches \\ 10.1. General Population}

The US Centers for Disease Control and Prevention (CDC) consider COVID-19 vaccines registered in the US (Pfizer/Biontech, Moderna, Janssen) to be interchangeable and equivalent in the general population [64]. The WHO considers the AstraZeneca/Oxford, Johnson \& Johnson, Moderna, Pfizer/BionTech, Sinopharm, Sinovac, COVAXIN, Covovax and Nuvaxovid vaccines to be safe and effective. These vaccines are equivalent in clinical practice, and healthcare professionals should use any available option [65]. The Australian guidelines prefer Moderna or Pfizer/Biontec vaccines in patients under 60 years over AstraZeneca [66].

\subsection{Pregnant Women}

In the US, vaccination of pregnant women is approved for all registered vaccines. According to the CDC, the most data on the efficacy and safety of COVID-19 vaccines in pregnant women is available for the Pfizer/Biontech vaccine [64]. In Australia, mRNA vaccines are recommended for pregnant women and nursing mothers [66]. The Russian national guidelines agree with the foreign regulators; however, they emphasize that the data on the safety of vaccines in nursing women are currently not enough for an unambiguous judgment about the safety of vaccines in this population [67].

\subsection{Children and Adolescents}

The US Food and Drug Administration (FDA) recommends the Pfizer/Biontech vaccine for children aged 12 to 17 years [68]. The WHO shares this opinion [65]. In Russia, COVID-19 vaccines in children and adolescents are being evaluated [67].

\subsection{Patients with a History of COVID-19}

The CDC recommends vaccination of patients with active COVID-19 infection after complete clinical recovery [64]. In a recent study, it was found that in patients who had had COVID-19, the levels of total and virus neutralizing antibodies were significantly higher than in patients who had had no contact with SARS-CoV-2 antigens [69]. Similar results were obtained for the AstraZeneca vaccine [70].

\subsection{Patients with Compromised Immune System}

The CDC recommends mRNA vaccines or the Janssen single-dose vaccine for immunocompromised patients. For mRNA vaccines, an additional vaccine dose is recommended for patients with immune suppression [64]. The Pfizer vaccine was approximately $20 \%$ less effective in patients with immune suppression compared to the general population [71]. The Canadian guidelines recommend that patients with primary immunodeficiency be vaccinated with mRNA vaccines, given the risk of more severe infection [71,72]. Vaccination is also approved for patients with primary immunodeficiency and a history of COVID-19 [73].

Available data suggest that widely available COVID-19 vaccines are generally interchangeable. Messenger RNA vaccines are considered to be safe in children and pregnant women. However, due to the short-term clinical use and the lack of convincing results, the following questions require further investigation: 
- Which vaccines are safer for patients over 60 years and those with severe concomitant diseases?

- How will the modification of vaccines for new coronavirus strains affect their clinical use?

- Is it possible to extrapolate the results of safety assessment of the Pfizer vaccine to the Moderna vaccine?

\section{Vaccination and SARS-CoV-2 Mutation}

Several authors pointed out the ability of SARS-CoV-2 to acquire mutations that can significantly reduce the effectiveness of vaccination $[74,75]$. To date, there have been six main variants of the virus that differ from the original virus found in China. The Alpha variant was first discovered in the UK in September 2020. This variant of SARS-CoV-2 includes viral strains characterized by 23 mutations, including 7 mutations and 2 deletions in RNA fragments encoding the $S$ protein [76]. This variant is characterized by significantly increased virulence and an increased risk of death or severe course of COVID-19 [77]. The Beta variant was first identified in the Republic of South Africa in December 2020. Mutations in strains belonging to the Beta variant include 9 mutations and 1 deletion in $S$ protein RNA [76]. The variant is characterized by a significant acceleration of spread of the disease compared with the reference strain [78]. Another variant of SARS-CoV-2, called Gamma, was found in patients arriving from Brazil in early 2021. In this variant, 12 mutations modify the structure of the $S$ protein, leading to an increase in virulence [76]. For the Delta variant, discovered in India in October 2020, there are 19 known S protein mutations, with 2 main mutations, L452R and E484Q, altering the structure of the RBD domain of the $\mathrm{S}$ protein. This variant is also characterized by an accelerated spread of the infection and the risk of more severe disease [76]. On 26 November 2021, the WHO designated variant B.1.1.529, called Omicron, as a Variant of Concern (VOC). This decision was based on evidence provided by the WHO Technical Advisory Group on SARS-CoV2 Virus Evolution (TAG-VE) that Omicron had several mutations that could affect its characteristics, such as how easily it spreads or the severity of the disease it causes [79]. The main concerns with Omicron are whether it is more infectious or serious than other VOCs and whether it might bypass vaccine-induced immunity.

Mutations in the S protein and, in particular, the RBD domain, are associated with a significant decrease in the neutralizing activity of antibodies in convalescents or vaccinated people (79). Clinical data indicated different effects of SARS-CoV-2 mutations on the efficacy of mRNA vaccines. A scientific review showed that some coronavirus variants may reduce the efficacy of neutralizing vaccine-induced antibodies, but the effect may be clinically non-significant [76].

A real-world study showed that the effectiveness of the Pfizer and AstraZeneca vaccines against the SARS-CoV-2 delta strain was reduced; however, the differences were clinically non-significant. Following the administration of a single dose of the vaccine, the effectiveness against the Alpha and Delta variants was $48.7 \%$ and $30.7 \%$, respectively. The administration of two doses of the Pfizer vaccine led to $93.7 \%$ protection against the infection caused by the Alpha variant and $88 \%$ protection in case of the Delta variant infection. For the AstraZeneca vaccine, the respective values were 74.5 and $67 \%$ [80]. CoronaVac vaccine was also less effective against the Delta variant; in a Chilean study, it was $67 \%$ effective in case of symptomatic Alpha variant infection, while in another real-world study, it was 59\% effective against the Delta strain [81]. In preclinical studies, Sputnik V vaccine showed high plasma activity against the Alpha variant and a moderate decrease in neutralizing activity against the Beta variant [82]. The efficacy of this vaccine in preventing hospitalization of patients with the Delta variant was $81 \%$ [83].

Subunit vaccines are potentially most susceptible to virus mutations, since they contain individual components of the virus or fragments of its proteins. For example, the effectiveness of the Novavax vaccine, which included the RBD domain, was two times lower in case of the Beta variant compared to the original SARS-CoV-2, being 50\% [84]. 
At the same time, it should be noted that the WHO-recommended threshold for vaccine effectiveness was 50\%, thus, despite the decrease in efficacy against the Delta strain, the level of protection still exceeded the recommended values to support the use of the vaccine.

Most COVID-19 vaccines target the S protein, which contains the largest number of immunogenic epitopes. To date, the approved vaccines remain effective; however, significant changes in the structure of the $S$ protein may lead to temporary absence of effective vaccines. One of the options for creating more universal vaccines that are effective over a long period of time is the creation of vaccines aimed at induction of an immune response to the internal SARS-CoV-2 antigens. This will help ensure a stable T-cell response and protect the vaccine against rapid mutation of the $S$ protein [85].

\section{Booster SARS-CoV-2 Immunization}

\subsection{Booster Immunization Approaches}

The CDC recommends a booster shot for patients $\geq 65$ years of age, long-stay patients, and patients aged 50-64 with concomitant diseases. It is recommended to administer the booster dose 6 months after completing the primary vaccination [86]. According to recent data, the Pfizer mRNA vaccine may provide relatively persistent immunity, therefore, some experts oppose booster immunization 6-12 months after the primary vaccination, as recommended by the vaccine developer [87]. In the UK, booster immunization with mRNA vaccines is currently recommended 6 months after completing the primary vaccination [88]. The EMA also states that booster doses are not required for patients from the general population who have received a full course of one of the approved vaccines [89].

At the time of this review, one of the issues that was being exhaustively discussed by both scientists and clinicians was the ethical aspect of booster immunization. In lowincome countries, there is currently a significant shortage of vaccines. Some clinicians point out the need to limit booster dosing to provide vaccines to the population of developing countries [90]. The world statistical data show that booster immunization is used in few countries, including the US, Russia, France, Germany, Turkey, and Chile, while the latter is the leader in the number of booster immunizations [91]. Notably, at the same time, the global rate of vaccination has decreased from 0.55 dose per 100 people/day at the end of June 2021 to 0.34 dose per 100 people/day at the end of January 2022 [92]. However, only $61 \%$ of the global population received at least one dose of a vaccine [93].

At the same time, the main regulatory authorities, as indicated above, do not recommend booster immunization for the general population. To determine the rationale and the need for additional doses of the vaccine, longer monitoring of vaccine efficacy in real-world clinical practice is necessary.

\subsection{Combination and Sequential Administration of Vaccines}

To date, data on the sequential administration and combination of different vaccines are very limited. One study found that the use of the AstraZeneca vaccine as the first dose and the Pfizer vaccine as the second one resulted in a significant increase in the immune response. In patients who received a combination of vaccines, an increased synthesis of antibodies to the RBD domain and S protein was noted. A 4 -fold increase in the cellular response to the vaccine was also observed compared to that noted following the administration of a single AstraZeneca vaccine dose. At the same time, a slight increase in the frequency of injection site reactions was noted [94]. There were some reports on a study of the AstraZeneca and Sputnik V vaccine combination. However, the results of the study have not yet been published [95].

In Cambodia, the national regulatory authority recommended the use of Sinovac vaccine as a booster vaccine for patients who had previously received AstraZeneca. Denmark suggests a vaccination course including AstraZeneca VVnr vaccine and one of the mRNA vaccines [96]. Thus, the approaches to booster immunization and the views on its rationale may differ significantly between countries. As demonstrated by the above data, the regulatory authorities do not recommend the combined use of VVnr vaccines, 
which is most likely due to the risk of a decrease in the immunogenicity of these vaccines. As stated above, all VVnr vaccines registered in one or more countries are based on only three different adenoviral vectors.

To find out the real need for repeated use of COVID-19 vaccines, it is necessary to perform epidemiological monitoring in the vaccinated populations for a longer period of time, as well as to obtain the results of studies evaluating the effectiveness and safety of vaccine combinations.

\section{Conclusions}

To date, there have been three following platforms playing a crucial role in the global strategy for COVID-19 vaccination: mRNA, VVnr, and inactivated virus vaccines. All of these platforms have some technological advantages and disadvantages:

- VVnr is a well-developed platform; however, these vaccines are technologically difficult to produce, and their long-term effectiveness is considered questionable by some expert groups.

- Messenger RNA vaccines have proven to be a technological breakthrough during the COVID-19 pandemic, as this class of vaccines was first approved for the COVID19 prophylaxis. They have shown good immunogenicity; however, they require special conditions for transportation and storage that lead to certain limitations on the conditions of their use.

- Inactivated vaccines are a classic platform. Despite the apparent simplicity of inactivated vaccine production, batch quality control remains a key issue for their use. The potential long-term efficacy of inactivated vaccines is also questionable.

- All common vaccines have been proven to have acceptable clinical efficacy, according to the $\mathrm{WHO}$ guidelines. However, it is becoming more important to consider vaccination in the following special patient groups: children and adolescents, pregnant women, the elderly, and patients with concomitant diseases, including those with impaired immunity. The use of vaccines in these groups of patients requires further research in order to provide guidelines for routine clinical practice. The effect of new SARS-CoV-2 mutations on the immunogenicity of vaccines and the long-term effectiveness of COVID-19 vaccination are also to be investigated, since it can only be established in long-term observational studies.

Overall, various groups of scientists and pharmaceutical companies have successfully met the challenge of developing effective and safe vaccines against COVID-19. We believe that the more vaccine platforms, the greater the potential for infection control. However, if necessary, the vaccines will need to be updated. However, there are still many issues that warrant further study.

Author Contributions: Conceptualization, D.K. and A.S.; methodology, D.K. and A.S.; software, D.K.; validation, D.K. and A.S.; formal analysis D.K. and A.S.; investigation, D.K. and A.S.; resources, D.K. and A.S.; data curation, D.K. and A.S.; writing-original draft preparation, D.K. and A.S.; writing-review and editing, D.K. and A.S.; visualization, D.K. and A.S.; supervision, A.S.; project administration, D.K. and A.S. All authors have read and agreed to the published version of the manuscript.

Funding: This research received no external funding.

Conflicts of Interest: The authors declare no conflict of interest.

\section{References}

1. WHO. Coronavirus (COVID-19) Dashboard. Available online: https://covid19.who.int (accessed on 22 November 2021).

2. Jackson, J.K.; Weiss, M.A.; Schwarzenberg, A.B.; Nelson, R.M.; Sutter, K.M.; Sutherland, M.D. Global Economic Effects of COVID-19. 2021. Available online: https:/ / fas.org/sgp/crs/row/R46270.pdf (accessed on 22 November 2021).

3. Singh, A.S.; Takhellambam, M.C.; Singh, A.S.; Takhellambam, M.C. COVID-19 pandemic wave: A global struggle and ways to control. Arch. Community Med. Public Health 2020, 6, 179-185. 
4. Pandey, K.R.; Subedee, A.; Khanal, B.; Koirala, B. COVID-19 control strategies and intervention effects in resource limited settings: A modeling study. PLoS ONE 2021, 16, e0252570. [CrossRef] [PubMed]

5. Farsalinos, K.; Poulas, K.; Kouretas, D.; Vantarakis, A.; Leotsinidis, M.; Kouvelas, D.; Docea, A.O.; Kostoff, R.; Gerotziafas, G.T.; Antoniou, M.N.; et al. Improved strategies to counter the COVID-19 pandemic: Lockdowns vs. primary and community healthcare. Toxicol. Rep. 2021, 8, 1-9. [CrossRef] [PubMed]

6. Information on COVID-19 Treatment, Prevention and Research. COVID-19 Treatment Guidelines. Available online: https: //www.covid19treatmentguidelines.nih.gov/ (accessed on 28 December 2021).

7. NICE. Overview I COVID-19 Rapid Guideline: Managing COVID-19 | Guidance I NICE. Available online: https:/ / www.nice.org. uk/guidance/ng191 (accessed on 28 December 2021).

8. COVID-19 Clinical Management: Living guidance. Available online: https://www.who.int/publications-detail-redirect/WHO2019-nCoV-clinical-2021-1 (accessed on 28 December 2021).

9. Ministry of Health of the Russian Federation. Temporary Guidelines for Prevention, Diagnosis, and Treatment of Coronavirus Disease (COVID-19). Version 14. 2022. Available online: Chrome-extension:/ / efaidnbmnnnibpcajpcglclefindmkaj/viewer.html? pdfurl=https \%3A\%2F\%2Fxn--80aesfpebagmfblc0a.xn--p1ai\%2Fai\%2Fdoc\%2F1213\%2Fattach\%2Fvmr_COVID-19_V14_27-122021.pdf\&clen $=4411121 \&$ chunk $=$ true (accessed on 28 December 2021).

10. Coronavirus (COVID-19) Vaccinations-Statistics and Research-Our World in Data. Available online: https://ourworldindata org/covid-vaccinations? country=RUS (accessed on 28 December 2021).

11. COVID-19 Vaccine Tracker I European Centre for Disease Prevention and Control. Available online: https://vaccinetracker.ecdc. europa.eu/public/extensions/COVID-19/vaccine-tracker.html\#uptake-tab (accessed on 28 December 2021).

12. Statista. COVID-19 Vaccination Rate in Russia 2021. Available online: https://www.statista.com/statistics/1239299/covid-19 -vaccination-rate-in-russia/ (accessed on 28 December 2021).

13. Russian Federation: WHO Coronavirus Disease (COVID-19) Dashboard with Vaccination Data. Available online: https://covid1 9.who.int/region/euro/country/ru (accessed on 28 December 2021).

14. The United Kingdom: WHO Coronavirus Disease (COVID-19) Dashboard with Vaccination Data. Available online: https: / / covid19.who.int/region/euro/country/gb (accessed on 28 December 2021).

15. COVID-19 Vaccine Tracker and Landscape. Available online: https://www.who.int/publications/m/item/draft-landscape-ofcovid-19-candidate-vaccines (accessed on 28 December 2021).

16. Vaccines-COVID19 Vaccine Tracker. Available online: https://covid19.trackvaccines.org/vaccines/approved/\#vaccine-list (accessed on 28 December 2021).

17. Limbach, K.J.; Paoletti, E. Non-replicating expression vectors: Applications in vaccine development and gene therapy. Epidemiol. Infect. 1996, 116, 241-256. [CrossRef]

18. Robert-Guroff, M. Replicating and non-replicating viral vectors for vaccine development. Curr. Opin. Biotechnol. 2007, 18, 546-556. [CrossRef]

19. Dicks, M.D.J.; Spencer, A.J.; Edwards, N.J.; Wadell, G.; Bojang, K.; Gilbert, S.C.; Hill, A.V.S.; Cottingham, M.G. A Novel Chimpanzee Adenovirus Vector with Low Human Seroprevalence: Improved Systems for Vector Derivation and Comparative Immunogenicity. Kremer EJ, editor. PLoS ONE 2012, 7, e40385. [CrossRef]

20. Folegatti, P.M.; Ewer, K.J.; Aley, P.K.; Angus, B.; Becker, S.; Belij-Rammerstorfer, S.; Bellamy, D.; Bibi, S.; Bittaye, M.; Clutterbuck , E.A.; et al. Safety and immunogenicity of the ChAdOx1 nCoV-19 vaccine against SARS-CoV-2: A preliminary report of a phase 1/2, single-blind, randomised controlled trial. Lancet 2020, 396, 467-478. [CrossRef]

21. Bos, R.; Rutten, L.; van der Lubbe, J.E.M.; Bakkers, M.J.G.; Hardenberg, G.; Wegmann, F.; Zuijdgeest, D.; de Wilde, A.H.; Koornneef, A.; Verwilligen, A.; et al. Ad26 vector-based COVID-19 vaccine encoding a prefusion-stabilized SARS-CoV-2 Spike immunogen induces potent humoral and cellular immune responses. npj Vaccines 2020, 5, 1-11. [CrossRef]

22. Custers, J.; Kim, D.; Leyssen, M.; Gurwith, M.; Tomaka, F.; Robertson, J.; Heijnen, E.; Condit, R.; Shukarev, G.; Heerwegh, D.; et al Vaccines based on replication incompetent Ad26 viral vectors: Standardized template with key considerations for a risk/benefit assessment. Vaccine 2021, 39, 3081-3101. [CrossRef]

23. Logunov, D.Y.; Dolzhikova, I.V.; Shcheblyakov, D.V.; Tukhvatulin, A.I.; Zubkova, O.V.; Dzharullaeva, A.S.; Kovyrshina, A.V.; Lubenets, N.L.; Grousova, D.M.; Erokhova, A.S.; et al. Safety and efficacy of an rAd26 and rAd5 vector-based heterologous prime-boost COVID-19 vaccine: An interim analysis of a randomised controlled phase 3 trial in Russia. Lancet 2021, 397, 671-681. [CrossRef]

24. Nogrady, B. Mounting evidence suggests Sputnik COVID vaccine is safe and effective. Nature 2021, 595, 339-340. [CrossRef] [PubMed]

25. Wu, S.; Huang, J.; Zhang, Z.; Wu, J.; Zhang, J.; Hu, H.; Zhu, T.; Zhang, J.; Luo, L.; Fan, P.; et al. Safety, tolerability, and immunogenicity of an aerosolised adenovirus type-5 vector-based COVID-19 vaccine (Ad5-nCoV) in adults: Preliminary report of an open-label and randomised phase 1 clinical trial. Lancet Infect. Dis. 2021. Available online: https://www.thelancet.com/ journals/laninf/article/PIIS1473-3099(21)00396-0/fulltext (accessed on 23 September 2021).

26. Henao-Restrepo, A.M.; Camacho, A.; Longini, I.M.; Watson, C.H.; Edmunds, W.J.; Egger, M.; Carroll, M.W.; Dean, N.E.; Diatta, I.; Doumbia, M.; et al. Efficacy and effectiveness of an rVSV-vectored vaccine in preventing Ebola virus disease: Final results from the Guinea ring vaccination, open-label, cluster-randomised trial (Ebola Ça Suffit!). Lancet 2017, 389, 505-518. [CrossRef] 
27. Steffensen, M.A.; Jensen, B.A.H.; Holst, P.J.; Bassi, M.R.; Christensen, J.P.; Thomsen, A.R. Pre-Existing Vector Immunity Does Not Prevent Replication Deficient Adenovirus from Inducing Efficient CD8 T-Cell Memory and Recall Responses. PLoS ONE 2012, 7, e34884. [CrossRef] [PubMed]

28. Tatsis, N.; Ertl, H.C.J. Adenoviruses as vaccine vectors. Mol. Ther. 2004, 10, 616-629. [CrossRef]

29. O'Riordan, C.R.; Lachapelle, A.; Delgado, C.; Parkes, V.; Wadsworth, S.C.; Smith, A.E.; Francis, G.E. PEGylation of Adenovirus with Retention of Infectivity and Protection from Neutralizing Antibody in Vitro and in Vivo. Hum. Gene Ther. 1999, 10, 1349-1358. [CrossRef]

30. 156. PEGylated Adenoviral Vaccines. Mol. Ther. 2008, 16, S59-S60. [CrossRef]

31. Leggiero, E.; Astone, D.; Cerullo, V.; Lombardo, B.; Mazzaccara, C.; Labruna, G.; Sacchetti, L.; Salvatore, F.; Croyle, M.; Pastore, L. PEGylated helper-dependent adenoviral vector expressing human Apo A-I for gene therapy in LDLR-deficient mice. Gene Ther. 2013, 20, 1124-1130. [CrossRef]

32. Sailaja, G.; HogenEsch, H.; North, A.; Hays, J.; Mittal, S.K. Encapsulation of recombinant adenovirus into alginate microspheres circumvents vector-specific immune response. Gene Ther. 2002, 9, 1722-1729. [CrossRef]

33. Pardi, N.; Hogan, M.J.; Porter, F.W.; Weissman, D. mRNA vaccines-A new era in vaccinology. Nat. Rev. Drug Discov. 2018, 17, 261-279. [CrossRef]

34. Bloom, K.; van den Berg, F.; Arbuthnot, P. Self-amplifying RNA vaccines for infectious diseases. Gene Ther. 2021, 28, 117-129. [CrossRef]

35. Mallapaty, S. India's DNA COVID vaccine is a world first-More are coming. Nature 2021, 597, 161-162. [CrossRef]

36. Vogel, A.B.; Lambert, L.; Kinnear, E.; Busse, D.; Erbar, S.; Reuter, K.C.; Wicke, L.; Perkovic, M.; Beissert, T.; Haas, H.; et al Self-Amplifying RNA Vaccines Give Equivalent Protection against Influenza to mRNA Vaccines but at Much Lower Doses. Mol. Ther. 2018, 26, 446-455. [CrossRef]

37. Corbett, K.S.; Edwards, D.K.; Leist, S.R.; Abiona, O.M.; Boyoglu-Barnum, S.; Gillespie, R.A.; Himansu, S.; Schäfer, A.; Ziwawo, C.T.; DiPiazza, A.T.; et al. SARS-CoV-2 mRNA vaccine design enabled by prototype pathogen preparedness. Nature 2020, 586, 567-571. [CrossRef] [PubMed]

38. Sahin, U.; Muik, A.; Derhovanessian, E.; Vogler, I.; Kranz, L.M.; Vormehr, M.; Baum, A.; Pascal, K.; Quandt, J.; Maurus, D.; et al. Concurrent Human Antibody and $\mathrm{T}_{\mathrm{H}} 1$ Type T-Cell Responses Elicited by a COVID-19 RNA Vaccine. Infectious Diseases (except HIV/AIDS); 2020 July. Available online: http:/ / medrxiv.org/lookup/doi/10.1101/2020.07.17.20140533 (accessed on 24 September 2021).

39. Crommelin, D.J.A.; Anchordoquy, T.J.; Volkin, D.B.; Jiskoot, W.; Mastrobattista, E. Addressing the Cold Reality of mRNA Vaccine Stability. J. Pharm. Sci. 2021, 110, 997-1001. [CrossRef] [PubMed]

40. Kyriakidis, N.C.; López-Cortés, A.; González, E.V.; Grimaldos, A.B.; Prado, E.O. SARS-CoV-2 vaccines strategies: A comprehensive review of phase 3 candidates. NPJ Vaccines 2021, 6, 28. [CrossRef] [PubMed]

41. Kisby, T.; Yilmazer, A.; Kostarelos, K. Reasons for success and lessons learnt from nanoscale vaccines against COVID-19. Nat. Nanotechnol. 2021, 16, 843-850. [CrossRef]

42. Federal Budgetary Research Institution State Research Center of Virology and Biotechnology “Vector." Simple, Blind, PlaceboControlled, Randomized Study of the Safety, Reactogenicity and Immunogenicity of Vaccine Based on Peptide Antigens for the Prevention of COVID-19 (EpiVacCorona), In Volunteers Aged 18-60 Years (I-II Phase). 2021. Report No.: NCT04527575. Available online: https:/ / clinicaltrials.gov/ct2/show / NCT04527575 (accessed on 22 September 2021).

43. Reuters. Volunteers Break Rank to Raise Doubts in Trial of Russia's Second COVID-19 Vaccine. 2021. Available online: https:/ / www.reuters.com/article/us-health-coronavirus-russia-vaccine-let-idUSKBN2BI2RJ (accessed on 22 September 2021).

44. $\quad$ Liang, Z.; Zhu, H.; Wang, X.; Jing, B.; Li, Z.; Xia, X.; Sun, H.; Yang, Y.; Zhang, W.; Shi, L.; et al. Adjuvants for Coronavirus Vaccines. Front. Immunol. 2020, 11, 2896. [CrossRef]

45. Creech, C.B.; Walker, S.C.; Samuels, R.J. SARS-CoV-2 Vaccines. JAMA 2021, 325, 1318-1320. [CrossRef]

46. Poland, G.A.; Ovsyannikova, I.G.; Kennedy, R.B. SARS-CoV-2 immunity: Review and applications to phase 3 vaccine candidates. Lancet 2020, 396, 1595-1606. [CrossRef]

47. Gao, Q.; Bao, L.; Mao, H.; Wang, L.; Xu, K.; Yang, M.; Li, Y.; Zhu, L.; Wang, N.; Lv, Z.; et al. Development of an inactivated vaccine candidate for SARS-CoV-2. Science 2020, 369, 77-81. [CrossRef]

48. Dai, X.; Xiong, Y.; Li, N.; Jian, C. Vaccine Types. In Vaccines-The History and Future; IntechOpen: London, UK, 2019. Available online: https:/ / www.intechopen.com/chapters/ 65813 (accessed on 24 September 2021).

49. Lim, W.W.; Mak, L.; Leung, G.M.; Cowling, B.J.; Peiris, M. Comparative immunogenicity of mRNA and inactivated vaccines against COVID-19. Lancet Microbe 2021, 2, e423. [CrossRef]

50. Cohn, L.; Delamarre, L. Dendritic Cell-Targeted Vaccines. Front. Immunol. 2014, 5, 255. [CrossRef]

51. Goyvaerts, C.; Breckpot, K. Pros and Cons of Antigen-Presenting Cell Targeted Tumor Vaccines. J. Immunol. Res. 2015, 2015, e785634. [CrossRef]

52. Ashraf, M.U.; Kim, Y.; Kumar, S.; Seo, D.; Ashraf, M.; Bae, Y.-S. COVID-19 Vaccines (Revisited) and Oral-Mucosal Vector System as a Potential Vaccine Platform. Vaccines 2021, 9, 171. [CrossRef] [PubMed]

53. European Medicines Agency. Clinical Evaluation of New Vaccines. Available online: https://www.ema.europa.eu/en/clinicalevaluation-new-vaccines (accessed on 24 September 2021). 
54. World Health Organization. Guidelines on Clinical Evaluation of Vaccines: Regulatory Expectations. 2016. Available online: https://www.who.int/biologicals/expert_committee/Clinical_changes_IK_final.pdf (accessed on 21 September 2021).

55. Polack, F.P.; Thomas, S.J.; Kitchin, N.; Absalon, J.; Gurtman, A.; Lockhart, S.; Perez, J.L.; Marc, G.P.; Moreira, E.D.; Zerbini, C.; et al. Safety and Efficacy of the BNT162b2 mRNA Covid-19 Vaccine. N. Engl. J. Med. 2020, 383, 2603-2615. [CrossRef] [PubMed]

56. Connors, M.; Graham, B.S.; Lane, H.C.; Fauci, A.S. SARS-CoV-2 Vaccines: Much Accomplished, Much to Learn. Ann. Intern. Med. 2021, 174, 687-690. [CrossRef] [PubMed]

57. El Sahly, H.M.; Baden, L.R.; Essink, B.; Doblecki-Lewis, S.; Martin, J.M.; Anderson, E.J.; Campbell, T.B.; Clark, J.; Jackson, L.A.; Fichtenbaum, C.J.; et al. Efficacy of the mRNA-1273 SARS-CoV-2 Vaccine at Completion of Blinded Phase. N. Engl. J. Med. 2021, 385, 1774-1785. [CrossRef] [PubMed]

58. Sadoff, J.; Gray, G.; Vandebosch, A.; Cárdenas, V.; Shukarev, G.; Grinsztejn, B.; Goepfert, P.A.; Truyers, C.; Fennema, H.; Spiessens, B.; et al. Safety and Efficacy of Single-Dose Ad26.COV2.S Vaccine against COVID-19. N. Engl. J. Med. 2021, 384, 2187-2201. [CrossRef]

59. Voysey, M.; Clemens, S.A.C.; Madhi, S.A.; Weckx, L.Y.; Folegatti, P.M.; Aley, P.K.; Angus, B.; Baillie, V.L.; Barnabas, S.L.; Bhorat, Q.E.; et al. Safety and efficacy of the ChAdOx1 nCoV-19 vaccine (AZD1222) against SARS-CoV-2: An interim analysis of four randomised controlled trials in Brazil, South Africa, and the UK. Lancet 2021, 397, 99-111. [CrossRef]

60. Evidence Assessment: Sinopharm/BBIBP COVID-19 Vaccine. 2021. Available online: https://cdn.who.int/media/docs/defaultsource/immunization/sage/2021/april/2_sage29apr2021_critical-evidence_sinopharm.pdf (accessed on 26 September 2021).

61. Tanriover, M.D.; Doğanay, H.L.; Akova, M.; Güner, H.R.; Azap, A.; Akhan, S.; Köse, s.; Erdinç, F.s.; Akalın, E.H.; Tabak, Ö.F.; et al. Efficacy and safety of an inactivated whole-virion SARS-CoV-2 vaccine (CoronaVac): Interim results of a double-blind, randomised, placebo-controlled, phase 3 trial in Turkey. Lancet 2021, 398, 213-222. [CrossRef]

62. Khoury, D.S.; Cromer, D.; Reynaldi, A.; Schlub, T.E.; Wheatley, A.K.; Juno, J.A.; Subbarao, K.; Kent, S.; Triccas, J.A.; Davenport, M.P.; et al. Neutralizing antibody levels are highly predictive of immune protection from symptomatic SARS-CoV-2 infection. Nat. Med. 2021, 27, 1205-1211. [CrossRef]

63. He, Q.; Mao, Q.; Zhang, J.; Bian, L.; Gao, F.; Wang, J.; Xu, M.; Liang, Z. COVID-19 Vaccines: Current Understanding on Immunogenicity, Safety, and Further Considerations. Front. Immunol. 2021, 12, 669339. [CrossRef]

64. Interim Clinical Considerations for Use of COVID-19 Vaccines I CDC. 2021. Available online: https://www.cdc.gov/vaccines / covid-19/clinical-considerations/covid-19-vaccines-us.html (accessed on 24 September 2021).

65. COVID-19 Vaccines Advice. Available online: https://www.who.int/emergencies/diseases/novel-coronavirus-2019/covid-19 -vaccines/advice (accessed on 28 December 2021).

66. Australian Government Department of Health. Health AGD of COVID-19 Vaccination-ATAGI Clinical Guidance on COVID-19 Vaccine in Australia in 2021. 2021. Available online: https://www.health.gov.au/resources/publications/covid-19-vaccinationatagi-clinical-guidance-on-covid-19-vaccine-in-australia-in-2021 (accessed on 24 September 2021).

67. Temporary Guidelines for Prevention, Diagnosis, and Treatment of Coronavirus Disease (COVID-19). Version 13. Available online: https: / / static-0.minzdrav.gov.ru/system/attachments/attaches/000/058/211/original/BMP-13.pdf (accessed on 14 October 2021).

68. Wallace, M. The Advisory Committee on Immunization Practices' Interim Recommendation for Use of Pfizer-BioNTech COVID-19 Vaccine in Adolescents Aged 12-15 Years-United States, May 2021. MMWR Morb. Mortal Wkly. Rep. 2021, 70, 749-752.

69. Racine-Brzostek, S.E.; Yee, J.; Sukhu, A.; Qiu, Y.; Rand, S.; Barone, P.; Hao, Y.; Yang, H.S.; Meng, Q.H.; Apple, F.S.; et al. More rapid, robust and sustainable antibody responses to mRNA COVID-19 vaccine in convalescent COVID-19 individuals. JCI Insight 2021, 6, e151477. [CrossRef]

70. Jamiruddin, R.; Haq, A.; Khondoker, M.U.; Ali, T.; Ahmed, F.; Khandker, S.S.; Jawad, I.; Hossain, R.; Ahmed, S.; Rahman, S.R.; et al. Antibody response to the first dose of AZD1222 vaccine in COVID-19 convalescent and uninfected individuals in Bangladesh. Expert Rev. Vaccines 2021, 20, 1561-1660. [CrossRef] [PubMed]

71. Chodick, G.; Tene, L.; Rotem, R.S.; Patalon, T.; Gazit, S.; Ben-Tov, A.; Weil, C.; Goldshtein, I.; Twig, G.; Cohen, D.; et al. The effectiveness of the TWO-DOSE BNT162b2 vaccine: Analysis of real-world data. Clin. Infect. Dis. 2021, ciab438. [CrossRef]

72. Roifman, C.M.; Vong, L. COVID-19 vaccination for patients with primary immunodeficiency. LymphoSign J. 2021, 8, 37-45. [CrossRef]

73. National Advisory Committee on Immunization (NACI). Summary of Updated NACI COVID-19 Vaccine Statement of May 3, 2021. Available online: https://www.canada.ca/content/dam/phac-aspc/documents/services/immunization/nationaladvisory-committee-on-immunization-naci/recommendations-use-covid-19-vaccines/summary-updated-statement-may-32021/NACI-summary-janssen-en.pdf (accessed on 8 October 2021).

74. Williams, T.C.; Burgers, W.A. SARS-CoV-2 evolution and vaccines: Cause for concern? Lancet Respir. Med. 2021, 9, 333-335. [CrossRef]

75. Egeren, D.V.; Novokhodko, A.; Stoddard, M.; Tran, U.; Zetter, B.; Rogers, M.; Pentelute, B.L.; Carlson, J.M.; Hixon, M.; Joseph-McCarthy, D.; et al. Risk of rapid evolutionary escape from biomedical interventions targeting SARS-CoV-2 spike protein. PLoS ONE 2021, 16, e0250780. [CrossRef] [PubMed]

76. Mohammadi, M.; Shayestehpour, M.; Mirzaei, H. The impact of spike mutated variants of SARS-CoV2 [Alpha, Beta, Gamma, Delta, and Lambda] on the efficacy of subunit recombinant vaccines. Braz. J. Infect. Dis. 2021, 25, 101606. [CrossRef] [PubMed] 
77. Altmann, D.M.; Boyton, R.J.; Beale, R. Immunity to SARS-CoV-2 variants of concern. Science 2021, 371, 1103-1104. [CrossRef] [PubMed]

78. Wang, P.; Nair, M.S.; Liu, L.; Iketani, S.; Luo, Y.; Guo, Y.; Wang, M.; Yu, J.; Zhang, B.; Kwong, P.D.; et al. Antibody resistance of SARS-CoV-2 variants B.1.351 and B.1.1.7. Nature 2021, 593, 130-135. [CrossRef]

79. WHO. Omicron Update. Available online: https://www.who.int/news/item/28-11-2021-update-on-omicron (accessed on 28 November 2021).

80. Weisblum, Y.; Schmidt, F.; Zhang, F.; DaSilva, J.; Poston, D.; Lorenzi, J.C.; Muecksch, F.; Rutkowska, M.; Hoffmann, H.-H.; Michailidis, E.; et al. Escape from Neutralizing Antibodies by SARS-CoV-2 Spike Protein Variants. eLife 2020, 9, e61312. [CrossRef] [PubMed]

81. Lopez Bernal, J.; Andrews, N.; Gower, C.; Gallagher, E.; Simmons, R.; Thelwall, S.; Stowe, J.; Tessier, E.; Groves, N.; Dabrera, G.; et al. Effectiveness of Covid-19 Vaccines against the B.1.617.2 (Delta) Variant. N. Engl. J. Med. 2021, 385, 585-594. [CrossRef] [PubMed]

82. Li, X.-N.; Huang, Y.; Wang, W.; Jing, Q.-L.; Zhang, C.-H.; Qin, P.-Z.; Guan, W.-J.; Gan, L.; Li, Y.-L.; Liu, W.-H.; et al. Effectiveness of inactivated SARS-CoV-2 vaccines against the Delta variant infection in Guangzhou: A test-negative case-control real-world study. Emerg. Microbes Infect. 2021, 10, 1751-1759. [CrossRef]

83. Ikegame, S.; Siddiquey, M.N.A.; Hung, C.-T.; Haas, G.; Brambilla, L.; Oguntuyo, K.Y.; Kowdle, S.; Chiu, H.-P.; Stevens, C.S.; Vilardo, A.E.; et al. Neutralizing activity of Sputnik V vaccine sera against SARS-CoV-2 variants. Nat. Commun. 2021, $12,4598$. [CrossRef] [PubMed]

84. Barchuk, A.; Cherkashin, M.; Bulina, A.; Berezina, N.; Rakova, T.; Kuplevatskaya, D.; Stanevich, O.; Skougarevskiy, D.; Okhotin, A. Vaccine Effectiveness against Referral to Hospital and Severe Lung Injury Associated with COVID-19: A Population-Based Case-Control Study in St. Petersburg, Russia. Epidemiology 2021. Available online: http://medrxiv.org/lookup/doi/10.1101/20 21.08.18.21262065 (accessed on 11 October 2021).

85. Callaway, E.; Mallapaty, S. Novavax offers first evidence that COVID vaccines protect people against variants. Nature 2021, 590, 17. [CrossRef]

86. Matta, S.; Rajpal, S.; Chopra, K.K.; Arora, V.K. Covid-19 vaccines and new mutant strains impacting the pandemic. Indian J. Tuberc. 2021, 68, 171-173. [CrossRef]

87. CDC. COVID-19 Vaccination. Centers for Disease Control and Prevention. 2020. Available online: https://www.cdc.gov/ coronavirus/2019-ncov/vaccines/booster-shot.html (accessed on 24 September 2021).

88. Pfizer/BioNTech's COVID-19 Vaccine Not to Require a Booster in 6-12 Months. Available online: https:/ / www.clinicaltrialsarena $\mathrm{com}$ /comment/ pfizer-biontechs-covid-19-vaccine-not-expected-to-require-a-booster-in-6-12-months-variant-of-concernspecific-shot-preferred/ (accessed on 24 September 2021).

89. GOV.UK. COVID-19 Vaccination: A Guide to Booster Vaccination. Available online: https://www.gov.uk/government/ publications / covid-19-vaccination-booster-dose-resources / covid-19-vaccination-a-guide-to-booster-vaccination (accessed on 24 September 2021).

90. European Medicines Agency. PINHO AC. ECDC and EMA Highlight Considerations for Additional Booster Doses of COVID-19 Vaccines. 2021. Available online: https://www.ema.europa.eu/en/news/ecdc-ema-highlight-considerations-additional-boosterdoses-covid-19-vaccines (accessed on 27 September 2021).

91. Jecker, N.S. Are COVID-19 Boosters Ethical, with Half the World Waiting for a First Shot? A Bioethicist Weighs in The Conversation. Available online: http:/ / theconversation.com/are-covid-19-boosters-ethical-with-half-the-world-waiting-for-a-first-shot-abioethicist-weighs-in-167606 (accessed on 27 September 2021).

92. Our World in Data. COVID-19 Data Explorer. Available online: https:/ / ourworldindata.org/coronavirus-data-explorer (accessed on 28 December 2021).

93. Daily COVID-19 Vaccine Doses Administered per 100 People. Our World in Data. Available online: https:/ / ourworldindata.org/ grapher/daily-covid-vaccination-doses-per-capita (accessed on 28 December 2021).

94. Ritchie, H.; Mathieu, E.; Rodés-Guirao, L.; Appel, C.; Giattino, C.; Ortiz-Ospina, E.; Roser, M.; Hasell, J. Coronavirus Pandemic (COVID-19). Our World in Data. 2020 March. Available online: https:/ / ourworldindata.org/covid-vaccinations (accessed on 28 December 2021).

95. Borobia, A.M.; Carcas, A.J.; Pérez Olmeda, M.T.; Castaño, L.; Jesús Bertrán, M.; García-Pérez, J.; Campins, M.; Portolés, A.; Gonzalez-Perez, M.; Morales, M.T.G.; et al. Reactogenicity and Immunogenicity of BNT162b2 in Subjects Having Received a First Dose of ChAdOx1s: Initial Results of a Randomised, Adaptive, Phase 2 Trial (CombiVacS); Social Science Research Network: Rochester, NY, USA, 2021; Report No.: ID 3854768. Available online: https:/ / papers.ssrn.com/abstract=3854768 (accessed on 24 September 2021).

96. Reuters. Factbox: Countries Weigh “Mix and Match" COVID-19 Vaccines. Reuters. 16 August 2021. Available online: https: //www.reuters.com/world/middle-east/countries-weigh-mix-match-covid-19-vaccines-2021-05-24/ (accessed on 24 September 2021). 